\title{
The Proteins in Nasal Secretion: A Longitudinal Study of the $\gamma$ A-Globulin, $\gamma$ G-Globulin, Albumin, Siderophilin, and Total Protein Concentrations in Nasal Washings from Adult Male Volunteers*
}

\author{
Roger D. Rossen, $†$ Arthur L. Schade, $\ddagger$ William T. Butler, and \\ Julius A. KASEL \\ (From the U.S. Department of Health, Education, and Welfare, Public Health Service, Na- \\ tional Institutes of Health, National Institute of Allergy and Infectious Diseases, \\ Laboratory of Clinical Investigations and Laboratory of Infectious Diseases, \\ Bethesda, Md.)
}

The long-standing observations that respiratory secretions contain virus-neutralizing substances (1-3) have recently been extended by the demonstration that antibody activity associated with the $\gamma \mathrm{A}$-globulin in nasal secretion may protect against respiratory virus infection (4). Since protection was most clearly seen in individuals with relatively high titers of nasal antibody, and since $\gamma \mathrm{A}$-globulin is known to be selectively accumulated in nasal secretion $(5,6)$, it seems possible that local concentrations of antibody globulin may be determined by at least two distinct but interrelated processes, 1) those concerned with synthesis of specific immunoglobulin, and 2) those involved in its delivery into the nasal secretions. The present investigation explores mechanisms involved in the delivery of immunoglobulin by examining the relationship between the mucus content and the concentrations of $\gamma \mathrm{A}$-globulin, $\gamma \mathrm{G}$-globulin, albumin, siderophilin, and total protein in nasal washings from normal volunteers.

\section{Methods}

Clinical and laboratory evaluation of volunteers. Subjects were 15 adult males who participated in an adenovirus vaccine trial and were not inoculated with live respiratory viruses. Throat and rectal swab specimens for virus isolation and nasopharyngeal swab specimens

* Submitted for publication November 22, 1965 ; accepted January 26, 1966.

An abstract of some of the findings has been published (Clin. Res. 1965, 13, 298).

$\dagger$ Address requests for reprints to Dr. Roger D. Rossen, Clinical Immunology Section, Laboratory of Clinical Investigations, National Institute of Allergy and Infectious Diseases, Bethesda, Md. 20014.

$\ddagger$ Laboratory of Infectious Diseases, Bethesda, Md. for bacterial culture were collected and processed by previously described methods (7).

Method of collecting nasal washings. The method of performing nasal washes has been described (6). In brief, it required instillation of $10 \mathrm{ml}$ of lactated Ringer's solution into the nasal passages, homogenization of the effluent, and separation of the soluble portion from the mucus and cellular debris by centrifugation. The volumes of the mucoid sediment and the supernatant were measured, and the two were stored separately at $-60^{\circ} \mathrm{C}$. All studies of nasal wash protein constituents were done on the supernatants.

Protein determinations. Total protein concentration was determined by the biuret method (8). Protein nitrogen contents of several samples were also tested by digestion and nesslerization. Total protein values $(\mathrm{N} \times$ 6.25) by this technique were one and one-half to two times as great as those obtained by the biuret method. A single pool of nasal washings from five volunteers, on the other hand, showed identical protein concentrations by biuret and micro-Kjeldahl methods $(\mathrm{N} \times 6.25)$.

Concentrations of $\gamma \mathrm{A}$-globulin, $\gamma \mathrm{G}$-globulin, and albumin were determined by the single radial diffusion method in agar (9). The following conditions were observed.

Antiserum was brought to the appropriate dilution in $0.2 \mathrm{M}$ sodium phosphate buffer, $\mathrm{pH} 8$, and incorporated into a $1 \%$ agar layer $1.5 \mathrm{~mm}$ thick. The antigen was allowed to diffuse at 4 to $6^{\circ} \mathrm{C}$ from wells $1.5 \mathrm{~mm}$ in diameter. At the end of the incubation period, the diameter of the leading edge of the precipitin ring surrounding the well was read to the nearest $0.1 \mathrm{~mm}$. Serial dilutions of a standard protein solution were included in each agar plate as controls.

For $\gamma \mathrm{A}$-globulin determinations, the agar contained goat antihuman $\gamma \mathrm{A}$-globulin diluted $1: 12 .{ }^{1}$ This antiserum was specific for $\gamma \mathrm{A}$-globulin in immunoelectrophoresis against whole human serum at several test dilutions. The $\gamma \mathrm{A}$-globulin used as a standard was prepared from pooled concentrated nasal washings by chromatography on DEAE cellulose, as described by Tomasi, Tan, Solo-

\footnotetext{
${ }^{1}$ Lot GP4-65, Hyland Laboratories, Los Angeles, Calif.
} 
mon, and Prendergast (10). When nasal washings for the pool were selected to contain minimal concentrations of $\gamma \mathrm{G}-$ globulin and no detectable siderophilin, the protein eluted with $0.1 \mathrm{M}$ sodium phosphate, $\mathrm{pH} 6.2$, gave a single line characteristic of $\gamma \mathrm{A}$-globulin on immunoelectrophoresis against antiwhole human serum. Trace contamination, however, by a protein not $\gamma \mathrm{A}$-globulin, could be demonstrated with antisera prepared against whole nasal washings. This preparation of $\gamma \mathrm{A}$-globulin was heterogeneous by analytical ultracentrifugation, its principal component having an $\mathrm{S}_{20}$, w of $11.1 \mathrm{~S}$ at a protein concentration of $1.8 \mathrm{mg}$ per $\mathrm{ml}$. The sedimentation properties of this purified $\boldsymbol{\gamma A}$-globulin were compared with those of $\gamma \mathrm{A}$-globulin in 14 samples of whole nasal wash studied by density gradient ultracentrifugation and were found to be quite similar (11). The minimal detectable concentration of $\gamma \mathrm{A}$-globulin was $0.10 \mathrm{mg}$ per $\mathrm{ml} \pm 0.03$ (2 SD).

Concentrations of $\gamma \mathrm{G}$-globulin were determined in agar by using goat antihuman $\gamma \mathrm{G}$-globulin in a final dilution of $1: 30 .^{2}$ At dilutions lower than $1: 4$ this antiserum showed trace activity by immunoelectrophoresis against $\gamma \mathrm{A}$ - and $\gamma \mathrm{M}$-globulins. A pool of $\gamma \mathrm{G}$-globulin, twice chromatographed on DEAE cellulose (12) after precipitation of extraneous plasma protein with 2-ethyoxy-6, 9 diamino-acridine-lactate (13), was used as the standard. This preparation of $\gamma \mathrm{G}$ gave a single line by immunoelectrophoresis against antiwhole human serum. It was homogeneous with a sedimentation coefficient of $6.8 \mathrm{~S}$ by sucrose density gradient ultracentrifugation. The minimal detectable concentration of $\gamma \mathrm{G}$-globulin was $0.10 \mathrm{mg}$ per $\mathrm{ml} \pm 0.08$ (2 SD).

For albumin determination, the agar contained a $1: 12$ dilution of goat antihuman albumin. ${ }^{3}$ By immunoelectrophoresis, this antiserum also developed a line for $\alpha_{1}$ glycoprotein at dilutions less than $1: 4$. The albumin standard had a sedimentation coefficient of $4.7 \mathrm{~S}$ by density gradient ultracentrifugation; it was $99.5 \%$ pure by paper electrophoresis, but on immunoelectrophoresis a trace contamination with $\alpha_{1}$ glycoprotein and orosomucoid could be demonstrated. The minimal detectable concentration of albumin was $0.03 \mathrm{mg}$ per $\mathrm{ml} \pm 0.02$ (2 SD).

Siderophilin concentrations were determined by a modification of the radioactive precipitin method of Woodworth and Schade (14). A series of standard solutions was made containing different known amounts of unlabeled siderophilin and a constant amount of ${ }^{50} \mathrm{Fe}$-labeled siderophilin. Rabbit antisiderophilin was then added to these standard solutions until further addition of antiserum no longer reduced the radioactivity of the supernatant of this antigen-antibody mixture. A standard curve was constructed that related the quantity of unlabeled material in the standard solutions to the quantity of antiserum required to precipitate the mixture of labeled and unlabeled siderophilin. Nasal wash siderophilin concentrations were then estimated by measuring the quantity of this rabbit antiserum required to precipitate

2 Lot GP5-65 from Hyland Laboratories.

3 Lot GP1064F from Hyland Laboratories. the radioactivity in a sample of nasal wash to which had been added a known amount of ${ }^{50} \mathrm{Fe}$-labeled siderophilin. Minimal detectable concentration was $0.003 \mathrm{mg}$ per $\mathrm{ml} \pm$ 0.003 (range).

Measurements of total protein, siderophilin, $\gamma \mathrm{A}-\mathrm{globu}-$ lin, $\gamma$ G-globulin, and albumin concentrations were performed directly on the supernates of all nasal wash specimens. In addition, measurements of $\gamma \mathrm{A}$-globulin, $\gamma \mathrm{G}$ globulin, and albumin were performed after the specimens had been dialyzed against distilled water, lyophilized, and reconstituted at one-tenth the original volume with normal saline. We found, however, that the corrected concentrations of $\gamma \mathrm{A}$-globulin, $\gamma \mathrm{G}$-globulin, and albumin determined on the lyophilized portion were, respectively, $40 \%, 70 \%$, and $10 \%$ less than the concentrations measured directly on the unlyophilized portion of the same specimens. Because of this, linear plots were constructed that related the concentration of each of the proteins in the lyophilized portion to its concentration in the original specimens. These graphs were used to estimate the actual protein values in specimens in which no protein was detectable on direct measurement. These corrections needed to be applied to only 3 of the 42 specimens tested for $\gamma \mathrm{A}$-globulin and albumin, but to 33 of 42 specimens tested for $\gamma \mathrm{G}$-globulin.

Immunoelectrophoresis was performed as described previously (6). All specimens were tested under identical conditions against the same lot of antiserum, 4 so that threshold concentrations for detection of the various serum proteins were the same for all specimens.

Test for occult blood. A portion of the centrifuged sediment was tested by the guaiac method.

\section{Results}

\section{Total protein content of nasal wash specimens}

Figure 1 shows the geometric means $\pm 95 \%$ confidence limits of the total protein concentrations of all specimens collected from each of the 15 volunteers. The total protein concentration of serial samples from any single volunteer varied over a narrow range, and the mean protein concentration of specimens from any individual tended to be the same whether his guaiac-positive or his guaiacnegative samples were used exclusively in making this calculation ( $p<0.01$, rank correlation test) (15). On the other hand, there was up to a fivefold difference in the mean total protein concentration from one volunteer to another. Day-to-day variation in the protein concentration of the nasal secretion was evaluated by assigning each specimen on each of the days of the study a rank score from 1 to 15 based on the total protein concentration of the specimen. Evaluation of these rank

4 IEP lot 3802 UI from Hyland Laboratories. 


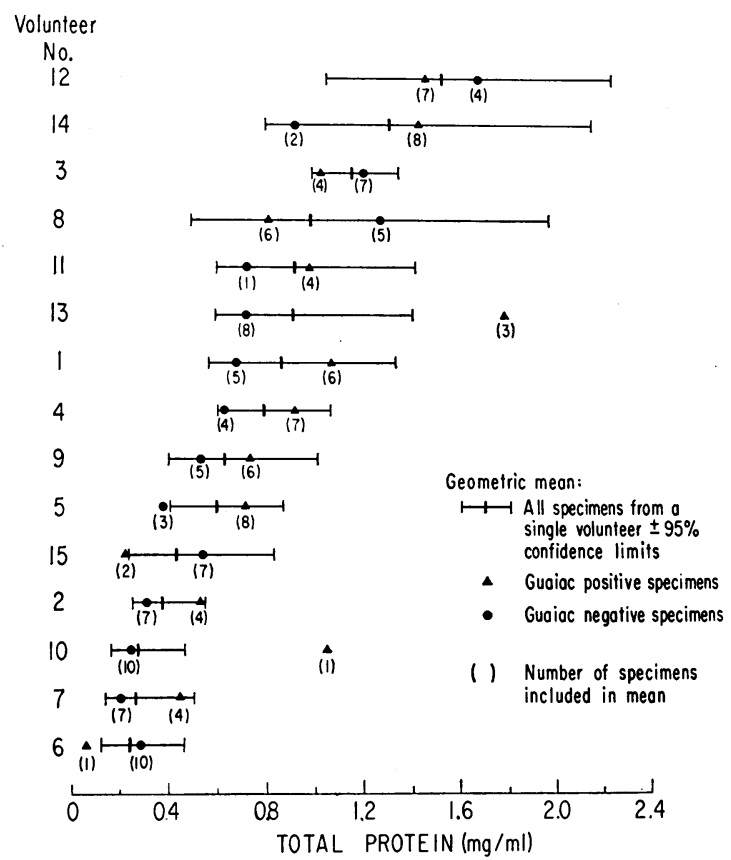

Fig. 1. Mean total protein concentration (biURET METHOD) OF ALL NASAL WASHINGS COLLECTED FROM EACH OF THE VOLUNTEERS OVER THE 27-DAY PERIOD OF OBSERVATION.

scores showed that there was a highly significant tendency for the protein concentrations of samples from any one volunteer to maintain the same rank throughout the study (Kendall coefficient of concordance, 14 degrees of freedom, chi square = 81.16, $\mathrm{p} \ll 0.001$ ) (16). Separate evaluation of only guaiac-positive or guaiac-negative specimens showed the same day-to-day constancy in the relative protein concentration of specimens from a single volunteer.

To evaluate the relationship between the protein concentration of the nasal wash specimens and the quantity of secretion collected by the nasal wash procedure, the volume of mucoid sediment recovered after centrifugation was used as an index of the amount of nasal secretion present in the specimens. Each specimen was given a rank score based on this volume. The scores representing mucus volume were also quite constant from day to day (Kendall coefficient of concordance, 14 degrees of freedom, chi square $=43.32, \mathrm{p}<0.001$ ). Moreover, comparison of the rank scores representing-mucus volumes with those representing protein concentration indicated that the amount of protein in the nasal wash sample was closely re- lated to the volume of mucoid material recovered with the specimen $(r=0.836, p<0.001$, rank correlation test on sums of ranks for mucus volume and total protein).

\section{Contribution of plasma to the nasal secretion pro- tein}

Immunoelectrophoretic studies. If transudation of plasma were unselective and a major source of protein in nasal secretion, one might expect to identify a large number of plasma protein components most frequently in specimens with high total protein concentrations. On the other hand, if minute breaks in capillary integrity were chiefly responsible for the plasma protein in nasal secre-

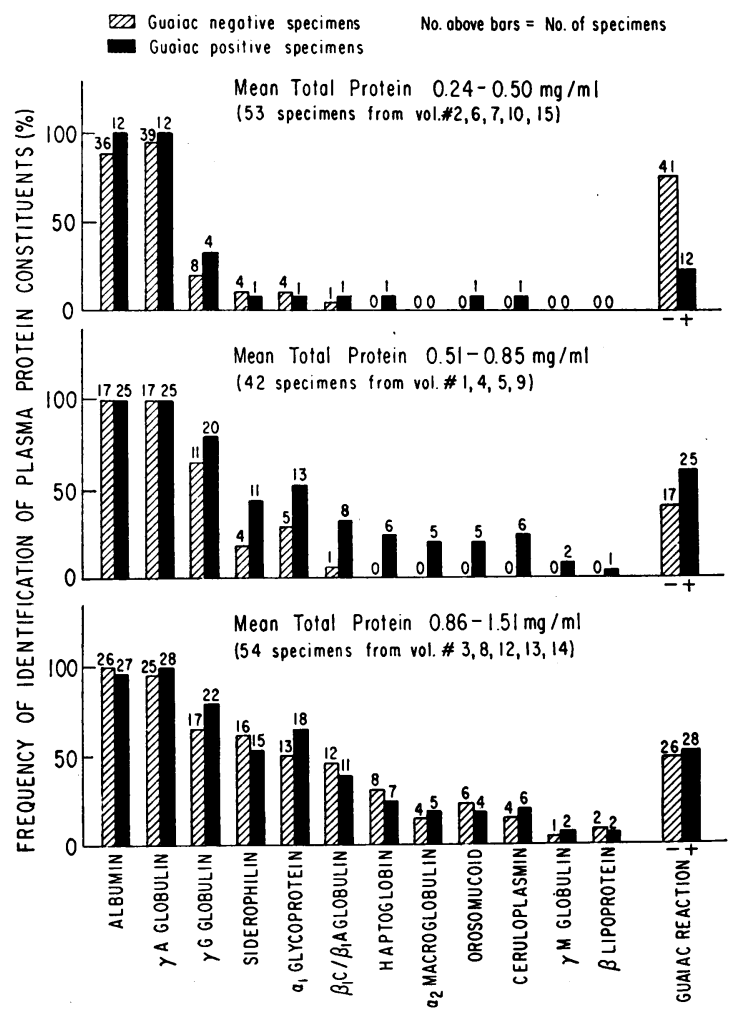

Fig. 2. FreQUency With Which 12 PLASMa PROTEIN COMPONENTS WERE IDENTIFIED BY IMMUNOELECTROPHORESIS IN NASAL WASHINGS FROM VOLUNTEERS WITH LOW (TOP PANEL), MODERATE (MIDDLE PANEL), AND HIGH (BOTTOM PANEL) NASAL WASH PROTEIN CONCENTRATIONS. The protein components are listed in order of the frequency with which they were detected in nasal wash. The column at the extreme right indicates the frequency of positive reactions for occult blood among the specimens in each group. Volunteer 11 was omitted because the number of guaiac-negative samples was inadequate. 
tion, one might expect that only guaiac-positive specimens would frequently contain a great number of plasma components. Immunoelectrophoretic studies (Figure 2 ) demonstrated that there was no significant difference in the frequency with which plasma protein components were identified in guaiac-positive and guaiac-negative nasal washings ( $p \geq 0.10$, chi square test) (15). Although specimens with high total protein concentrations frequently did contain a large number of plasma proteins, components such as albumin, $\gamma \mathrm{A}$-globulin, and $\gamma$ G-globulin were identified in most specimens irrespective of their total protein concentration.

Quantitative evaluation. To evaluate the above observations further, we determined the albumin, $\gamma \mathrm{G}$-globulin, $\gamma \mathrm{A}$-globulin, and siderophilin concentrations of three guaiac-negative specimens from each volunteer. Specimens were chosen to give, where possible, a sampling of days during the month of study. The mean values for those determinations are shown in Table I.

Of the four proteins tested, $\gamma \mathrm{A}$-globulin was present in the highest concentrations and accounted for a considerably greater percentage of the total protein (21 to $53 \%$ ) than in serum (17). Concentration of $\gamma \mathrm{G}$-globulin varied from 5 to $14 \%$, whereas albumin levels were 2 to $9 \%$ of total protein. Mean siderophilin concentrations extended from 0 to $2.5 \%$ of the total protein. The average quantity of total protein accounted for by these four components was $45 \%$, and it ranged from $31 \%$ in specimens from Volunteer 3 to $73 \%$ in those from Volunteer 5. In all cases, a substantial portion of the protein remained unclassified.

When the mean concentrations in Table I were compared, total protein correlated closely with the concentrations of $\gamma \mathrm{A}$-globulin $(\mathrm{r}=0.869), \gamma \mathrm{G}-$ globulin $(r=0.776)$, and albumin $(r=0.662)$ ( $p<0.01$, rank correlation test), whereas there was no correlation between any of these and the mean siderophilin concentration. Moreover, when individual values for $\gamma \mathrm{A}$-globulin or albumin in serial nasal wash specimens from a single volunteer were examined, they exhibited the same tendency to remain constant from day to day as did the total protein [analysis of variance (15), $\mathrm{F}$ ratio for $\gamma \mathrm{A}$-globulin $=3.29, \mathrm{p}=0.01 ; \mathrm{F}$ ratio for albumin $=2.31, \mathrm{p}<0.05]$. Individual values for $\gamma$ G-globulin and siderophilin in repeated samples from a single volunteer, however, showed greater variability, and no day-to-day constancy in their concentrations was demonstrated ( $F$ ratio $\leq 1.50$, $\mathrm{p}>0.05$, analysis of variance). Indeed, there was no correlation between the siderophilin concentration and that of any of the other measured components in individual specimens $(p>0.05$, rank correlation test).

Table II shows a comparison between the albumin and siderophilin concentrations in specimens from each of 14 volunteers. When detected,

TABLE I

Geometric mean $\gamma A$-globulin, $\gamma G$-globulin, albumin, and siderophilin concentrations in guaiac-negative nasal wash from 14 volunteers*

\begin{tabular}{|c|c|c|c|c|c|c|c|}
\hline Volunteer & $\begin{array}{l}\text { No. of } \\
\text { specimens } \\
\text { examined }\end{array}$ & Mean TP† & $\gamma \mathrm{A}-\mathrm{globulin} \ddagger$ & $\gamma$ G-globulin $\ddagger$ & Albumin $\ddagger$ & Siderophilin $\ddagger$ & $\begin{array}{c}\text { TP } \\
\text { accounted } \\
\text { for }\end{array}$ \\
\hline & & $\mu g / m l$ & & & & & $\%$ \\
\hline 12 & 3 & 1,752 & $481(27)$ & $90(5)$ & $81(5)$ & $10(0.6)$ & 38 \\
\hline 8 & 3 & 1,595 & $592(37)$ & $105(7)$ & 50 (3) & $9(0.6)$ & 47 \\
\hline 3 & 3 & 1,400 & 325 (23) & $74(5)$ & $27(2)$ & $5(0.4)$ & 31 \\
\hline 13 & 3 & 1,250 & $277(22)$ & $58(5)$ & $60(5)$ & $11(0.9)$ & 32 \\
\hline 14 & 2 & 895 & $252(28)$ & $63(7)$ & 79 (9) & $19(2.1)$ & 46 \\
\hline 15 & 3 & 785 & 230 (29) & $65(8)$ & $34(4)$ & $9(1.1)$ & 43 \\
\hline 1 & 3 & 765 & $235(31)$ & $55(7)$ & $23(3)$ & $0(0)$ & 41 \\
\hline 6 & 3 & 606 & 176 (29) & $42(7)$ & $26(4)$ & $5(0.8)$ & 41 \\
\hline 9 & 4 & 590 & 205 (35) & 31 (5) & $24(4)$ & $15(2.5)$ & 47 \\
\hline 4 & 3 & 578 & $216(37)$ & $71(12)$ & $33(6)$ & $11(2.0)$ & 57 \\
\hline 7 & 3 & 500 & $106(21)$ & $31(6)$ & $19(4)$ & $9(2.0)$ & 33 \\
\hline 10 & 3 & 478 & 113 (24) & $52(11)$ & $23(5)$ & $7(1.5)$ & 41 \\
\hline 2 & 3 & 397 & $212(53)$ & $25(6)$ & $24(6)$ & $2(0.5)$ & 66 \\
\hline 5 & 3 & 370 & $178(48)$ & 53 (14) & 32 (9) & $6(1.6)$ & 73 \\
\hline
\end{tabular}

* Volunteer 11 was omitted because the number of guaiac-negative samples available was inadequate.

$+\mathrm{TP}=$ total protein.

$\$$ The number enclosed in parentheses is the per cent of TP; the other number is the mean concentration, expressed as micrograms per milliliter. 
TABLE II

Concentration of albumin and siderophilin in individual guaiac-negative nasal wash specimens

\begin{tabular}{|c|c|c|c|c|c|c|c|c|c|}
\hline $\begin{array}{l}\text { Volun- } \\
\text { teer* }\end{array}$ & $\begin{array}{c}\text { Day } \\
\text { of } \\
\text { study }\end{array}$ & $\underset{\text { min }}{\text { Albu- }}$ & $\begin{array}{c}\text { Sider- } \\
\text { ophilin }\end{array}$ & $\begin{array}{c}\text { [Sider- } \\
\text { ophilin]/ } \\
\text { [Albumin] }\end{array}$ & $\begin{array}{l}\text { Volun- } \\
\text { teer* }\end{array}$ & $\begin{array}{l}\text { Day } \\
\text { of } \\
\text { study }\end{array}$ & $\underset{\min }{\text { Albu- }}$ & $\begin{array}{l}\text { Sider- } \\
\text { ophilin }\end{array}$ & $\begin{array}{c}\text { [Sider- } \\
\text { ophilin]/ } \\
\text { [Albumin]† }\end{array}$ \\
\hline 12 & $\begin{array}{r}1 \\
2 \\
12\end{array}$ & $\begin{array}{r}158 \\
33 \\
100\end{array}$ & $\begin{array}{r}26 \\
0 \\
18\end{array}$ & $\begin{array}{l}0.16 \\
0.18\end{array}$ & 6 & $\begin{array}{r}8 \\
12 \\
14\end{array}$ & $\begin{array}{l}23 \\
37 \\
20\end{array}$ & $\begin{array}{l}7 \\
0 \\
7\end{array}$ & $\begin{array}{l}0.30 \\
0.35\end{array}$ \\
\hline 8 & $\begin{array}{r}8 \\
12 \\
27\end{array}$ & $\begin{array}{l}75 \\
50 \\
33\end{array}$ & $\begin{array}{r}17 \\
18 \\
0\end{array}$ & $\begin{array}{l}0.23 \\
0.36\end{array}$ & 9 & $\begin{array}{r}1 \\
8 \\
21\end{array}$ & $\begin{array}{l}20 \\
40 \\
18\end{array}$ & $\begin{array}{l}11 \\
18 \\
18\end{array}$ & $\begin{array}{l}0.55 \\
0.45 \\
1.00\end{array}$ \\
\hline 3 & $\begin{array}{r}8 \\
10 \\
18\end{array}$ & $\begin{array}{l}28 \\
14 \\
50\end{array}$ & $\begin{array}{r}0 \\
0 \\
30\end{array}$ & 0.60 & 4 & $\begin{array}{r}1 \\
12 \\
18\end{array}$ & $\begin{array}{l}33 \\
40 \\
28\end{array}$ & $\begin{array}{r}0 \\
39 \\
18\end{array}$ & $\begin{array}{l}0.98 \\
0.64\end{array}$ \\
\hline 13 & $\begin{array}{l}12 \\
21 \\
27\end{array}$ & $\begin{array}{r}75 \\
26 \\
108\end{array}$ & $\begin{array}{r}0 \\
18 \\
39\end{array}$ & $\begin{array}{l}0.69 \\
0.36\end{array}$ & 7 & $\begin{array}{r}8 \\
12 \\
21\end{array}$ & $\begin{array}{l}22 \\
16 \\
20\end{array}$ & $\begin{array}{r}0 \\
18 \\
22\end{array}$ & $\begin{array}{l}1.13 \\
1.10\end{array}$ \\
\hline 14 & $\begin{array}{r}2 \\
27\end{array}$ & $\begin{array}{r}220 \\
28\end{array}$ & $\begin{array}{r}39 \\
9\end{array}$ & $\begin{array}{l}0.18 \\
0.32\end{array}$ & 10 & $\begin{array}{r}1 \\
8 \\
10\end{array}$ & $\begin{array}{l}18 \\
33 \\
20\end{array}$ & $\begin{array}{r}11 \\
18 \\
0\end{array}$ & $\begin{array}{l}0.61 \\
0.55\end{array}$ \\
\hline 15 & $\begin{array}{l}2 \\
4 \\
8\end{array}$ & $\begin{array}{l}26 \\
37 \\
40\end{array}$ & $\begin{array}{r}18 \\
0 \\
22\end{array}$ & $\begin{array}{l}0.69 \\
0.55\end{array}$ & 2 & $\begin{array}{r}8 \\
12 \\
14\end{array}$ & $\begin{array}{l}33 \\
20 \\
20\end{array}$ & $\begin{array}{l}0 \\
3 \\
0\end{array}$ & 0.15 \\
\hline 1 & $\begin{array}{r}8 \\
10 \\
18\end{array}$ & $\begin{array}{l}33 \\
16 \\
24\end{array}$ & $\begin{array}{l}0 \\
0 \\
0\end{array}$ & & 5 & $\begin{array}{l}1 \\
4 \\
8\end{array}$ & $\begin{array}{l}58 \\
20 \\
28\end{array}$ & $\begin{array}{r}17 \\
7 \\
0\end{array}$ & $\begin{array}{l}0.29 \\
0.35\end{array}$ \\
\hline
\end{tabular}

$\dagger$ Ratios in normal serum $=0.08$; serum concentrations $=$ albumin, $40 \mathrm{mg}$ per $\mathrm{ml}$; siderophilin, $3 \mathrm{mg}$ per $\mathrm{ml}$.

* Volunteer 11 omitted (see first footnote to Table I).

siderophilin levels often approached or exceeded albumin concentrations. In each instance, siderophilin to albumin concentration ratios were higher than would be expected if passive transudation governed the delivery of these proteins into nasal secretion equally. Concentrations of $\gamma \mathrm{G}$-globulin commonly exceeded albumin levels as well (Table I). The mean $\gamma$ G-globulin to albumin concentration ratio in 43 individual nasal wash specimens was 1.8 (range, 0.6 to 5.6), whereas a concentration ratio of $12 / 40 \mathrm{mg}$ per $\mathrm{ml}(0.3)$ might be considered normal for whole serum (18). Neither siderophilin nor $\gamma$ G-globulin, however, approached the uniformly high concentrations attained by $\gamma$ A-globulin. This protein was the only measured component whose concentration in nasal wash relative to total protein was consistently higher than its plasma concentration.

\section{Analysis of clinical data on the volunteers}

There was no association between the mean nasal wash protein level and history or present evidence of sinusitis, evidence of acute upper respiratory disease, or status of nasal bacterial or viral flora in any of the volunteers (Table III).

\section{Discussion}

In serial nasal washings from any one volunteer, both total protein concentration and volume of mucoid material remained constant over an interval of nearly 1 month, whereas protein levels varied as much as fivefold from one person to another. The observation that specimens from volunteers with high nasal wash protein concentrations tended also to have large volumes of mucoid sediment suggests that protein concentration was a function of the amount of nasal secretion recovered by the collection procedure. Presupposing that the volume of mucus in the specimen bore a constant relationship to the quantity of secretion in the nasal passages, one may postulate that the consistent differences among volunteers in nasal wash protein and mucus content were due to differences in the amount of nasal secretion available for collec- 
NASAL SECRETION PROTEINS

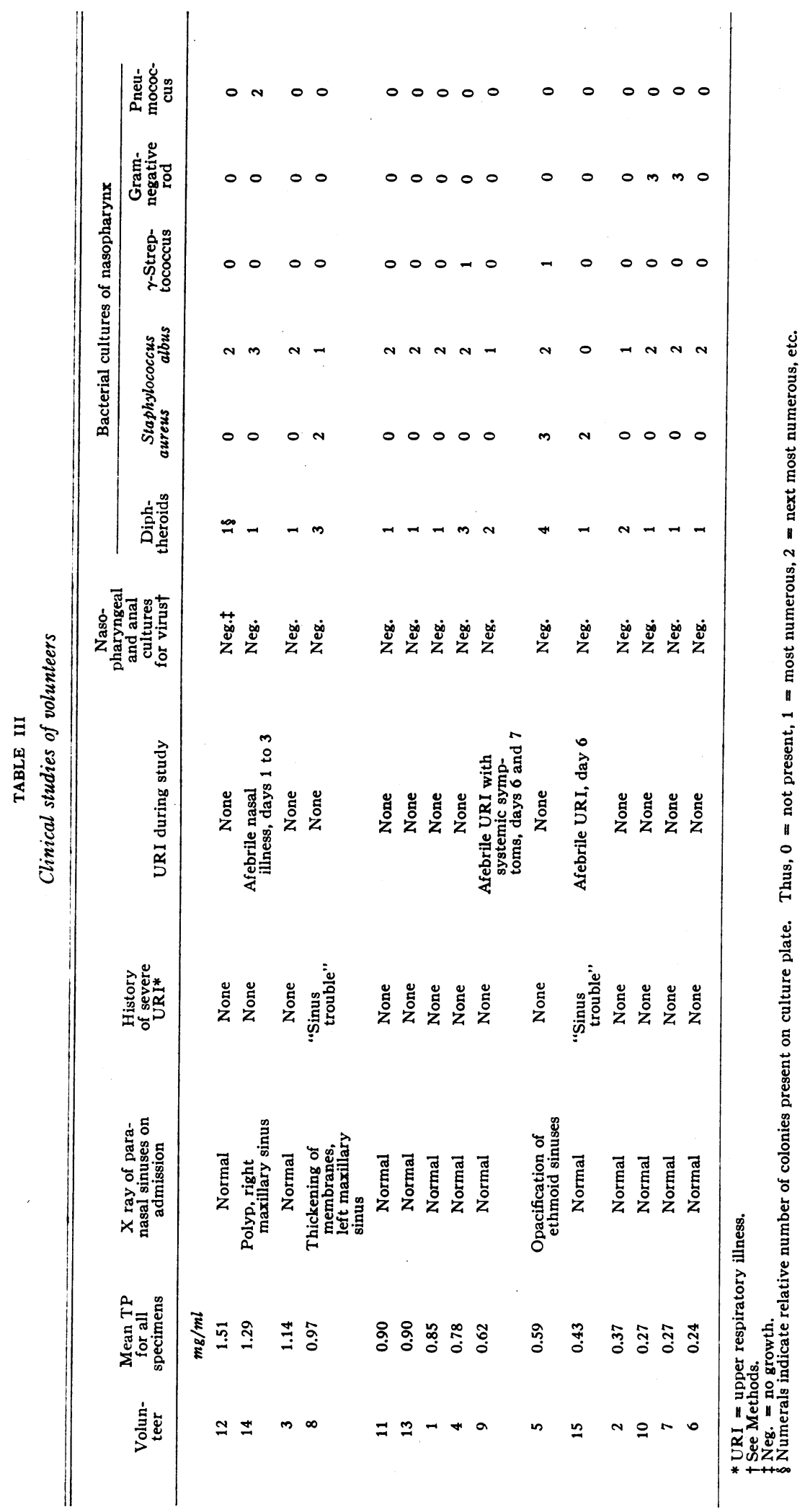


tion. There was no evidence that collection of secretions was consistently more complete in some volunteers than in others. No volunteer showed a special tendency to swallow the nasal washings, and the technique and conditions for collection were the same in all. The nearly equivalent protein concentrations and composition of guaiacpositive and guaiac-negative specimens from any single individual suggest, moreover, that small traces of whole blood did not contribute to the higher protein concentrations or larger mucus volumes of specimens from some volunteers. It appears likely, therefore, that these findings represent one aspect of constitutional variation, possibly due to differences among individuals in the production or retention of secretions in the nasal passages. However, other factors, such as differences in the physicochemical composition of secretion or in nasal anatomy may have contributed to the differences observed.

Of the many plasma protein components found in nasal washings, $\gamma \mathrm{A}$-globulin, $\gamma \mathrm{G}$-globulin, albumin, and siderophilin accounted for slightly less than one-half of the total protein. Since the immunoelectrophoretic studies indicated that other plasma proteins probably do not contribute consistently and significantly to nasal secretion protein, a considerable portion remains unclassified. The contribution of proteins not recognized by antisera to whole human serum is currently under investigation.

Of the four measured components, $\gamma \mathrm{A}$-globulin accounted for the greatest proportion of the total protein ( 21 to $53 \%$ ), and one may question, therefore, whether an accurate estimation of the concentration of this protein was obtained. It has been demonstrated that $\gamma \mathrm{A}$-globulin, both in sera (19) and parotid and mammary secretions (10), may exhibit considerable size heterogeneity. If the distribution of $\gamma \mathrm{A}$-globulin molecules in our reference standard were different from that of the specimens tested, then the estimation of $\gamma \mathrm{A}$-globulin concentration might not have been valid. However, this possibility seems unlikely, since the reference standard was a preparation of $\gamma \mathrm{A}$-globulin purified from pooled nasal washings with sedimentation properties similar to those of $\gamma \mathrm{A}$-globulin in whole nasal wash (11).

The demonstration that $\gamma \mathrm{A}$-globulin in nasal secretion may be present in concentrations con- siderably higher in relation to total protein than in serum (17) extends the work of Remington, Vosti, Lietze, and Zimmerman (5) and suggests that the immune system of the nasal tissues may be similar to that of parotid and mammary glands, as described in the recent investigations of Tomasi and associates (10). Their work, confirmed in part by McFarlin, Strober, Wochner, and Waldmann (20), suggested that the parotid gland may participate in the synthesis of $\gamma \mathrm{A}$-globulin discharged into its secretions. However, transport of this immunoglobulin from plasma with subsequent modification of the protein by the gland could not be wholly excluded.

Although a direct relationship between the quantity of immunoglobulin in nasal washings and resistance to infection has not been demonstrated in this study, it has recently been shown elsewhere (4) that protection against rhinovirus infection correlates with the titer of antibody activity recovered in nasal washings as well as the titer of antibody in serum. Nasal washings of a few individuals who became infected failed to reflect their high serum antibody levels. The present work suggests that, quite apart from variations in the ability to synthesize specific globulin, differences among individuals in the quantity of antibody locally available may be determined by factors that regulate the production or retention of nasal secretion.

In contrast to $\gamma \mathrm{A}$-globulin, nasal wash concentrations of $\gamma \mathrm{G}$-globulin, albumin, and siderophilin relative to total protein were less than in serum. Whereas the mechanisms by which these are incorporated into nasal secretion are also not understood, it is evident that if they are passively incorporated from plasma, the barrier to transudation must be less restrictive for both siderophilin and $\gamma \mathrm{G}$-globulin than for albumin. If other factors that influence the passage of proteins across cell membranes are equal, the smaller molecular size of albumin $(60,000 \mathrm{~mol} \mathrm{wt})$ compared to siderophilin $(90,000 \mathrm{~mol} w \mathrm{t})$ or $\gamma \mathrm{G}$-globulin (150,$000 \mathrm{~mol} \mathrm{wt}$ ), and the higher concentration gradient for albumin across the nasal vascular membranes would be expected to produce much lower siderophilin to albumin and $\gamma \mathrm{G}$-globulin to albumin concentration ratios than were observed. Since the immunologic method used to measure nasal wash albumin levels when tested against sera 
gave values $25 \%$ higher than a standard method (21) utilizing the dye-binding properties of albumin, it is improbable that the ratios observed resulted from any underestimation of nasal wash albumin concentrations.

The failure to detect siderophilin consistently in serial specimens from the same individual and the lack of correlation between the siderophilin concentration and the concentrations of $\gamma \mathrm{A}$-globulin, $\gamma$ G-globulin, albumin, or total protein in individual specimens suggest the possibility that tissues, such as those of the paranasal sinuses, that may discharge secretions intermittently are chiefly responsible for the incorporation of siderophilin into nasal secretion.

Although a biological role for siderophilin in nasal secretion is not defined, it is reasonable to assume that in this environment it serves as a nonspecific antibacterial agent. In its iron-free form, siderophilin exerts a broad spectrum of bacteriostatic activity that is concentration dependent only in that the amount of siderophilin must be sufficient to chelate all soluble iron present in its milieu (22). Thus, even at the low concentrations of siderophilin present in nasal secretion, it is possible that this protein inhibits the development of many pathogens with restrictive nutritional iron requirements.

\section{Summary}

Eleven nasal wash specimens were collected from each of 15 volunteers during a 27 -day period. The mucus volume and total protein concentration of these specimens were determined, and each specimen was studied by immunoelectrophoresis to characterize qualitatively its content of plasma proteins. Quantitative estimations of $\gamma \mathrm{A}$-globulin, $\gamma \mathrm{G}$-globulin, albumin, and siderophilin concentrations were made on several specimens from each of the volunteers.

The total protein concentration and mucus volume of serial nasal wash specimens from a single volunteer were relatively constant over the test period, whereas there was considerable variation in protein concentration among samples from different volunteers. Differences in protein levels among volunteers were not correlated with acute or chronic respiratory illness or marked differences in nasal bacterial flora.
Between 21 and $53 \%$ of the total nasal wash protein was accounted for by $\gamma \mathrm{A}$-globulin. $\gamma \mathrm{G}$-Globulin contributed 5 to $14 \%$, albumin 2 to $9 \%$, and siderophilin 0 to $2.5 \%$ of the total protein. In any one volunteer, the four measured components accounted for between 31 and $73 \%$ of the total protein. The concentrations of $\gamma \mathrm{G}$-globulin and siderophilin observed in these specimens suggest that, in relation to concentrations of albumin present, $\gamma \mathrm{G}$-globulin and siderophilin accumulate selectively in nasal secretions.

\section{Acknowledgments}

The assistance of Dr. David W. Alling in the statistical evaluation of the data and the competent technical assistance of Mr. Clarence Szwed are gratefully acknowledged.

\section{References}

1. Amoss, H. L., and E. Taylor. Neutralization of the virus of poliomyelitis by nasal washings. J. exp. Med. 1917, 25, 507.

2. Howitt, B. F. Relationship between nasal and humoral antipoliomyelitic substances. J. infect. Dis. 1937, 60, 113.

3. Bell, E. J. The relationship between the antipoliomyelitic properties of human nasopharyngeal secretions and blood serums. Amer. J. Hyg. 1948, $47,351$.

4. Cate, T. R., R. D. Rossen, R. G. Douglas, Jr., W. T. Butler, and R. B. Couch. The role of nasal secretion and serum antibody in the rhinovirus common cold. Amer. J. Epidemiol. In press.

5. Remington, J. S., K. L. Vosti, A. Lietze, and A. L. Zimmerman. Serum proteins and antibody activity in human nasal secretions. J. clin. Invest. 1964, 43, 1613.

6. Rossen, R. D., W. T. Butler, T. R. Cate, C. F. Szwed, and R. B. Couch. Protein composition of nasal secretion during respiratory virus infection. Proc. Soc. exp. Biol. (N. Y.) 1965, 119, 1169.

7. Banks, P. A., J. A. Kasel, M. Huber, R. H. Alford, and V. Knight. Persistence of neutralizing antibody in adult volunteers immunized with adenovirus soluble antigen. Proc. Soc. exp. Biol. (N. Y.) 1966, 121, 240.

8. Kabat, E. A., and M. M. Mayer. Experimental Immunochemistry, 2nd ed. Springfield, Ill., Charles C Thomas, 1961, p. 559.

9. Feinberg, J. G. Identification, discrimination and quantification in Ouchterlony gel plates. Int. Arch. Allergy 1957, 11, 129.

10. Tomasi, T. B., Jr., E. M. Tan, A. Solomon, and R. A. Prendergast. Characteristics of an immune system common to certain external secretions. J. exp. Med. 1965, 121, 101. 
11. Rossen, R. D., W. T. Butler, W. E. Vannier, R. G. Douglas, Jr., R. B. Couch, and A. G. Steinberg. The sedimentation and antigenic properties of proteins in nasal and other external secretions. Submitted for publication.

12. Sober, H. A., F. J. Gutter, M. M. Wyckoff, and E. A. Peterson. Chromatography of proteins. II. Fractionation of serum protein on anion-exchange cellulose. J. Amer. chem. Soc. 1956, 78, 756.

13. Pennell, R. B. Fractionation and isolation of purified components by precipitation methods in The Plasma Proteins, F. W. Putnam, Ed. New York, Academic Press, 1960, p. 35.

14. Woodworth, R. C., and A. L. Schade. Immunological precipitin titrations based on radioactive tagging of the iron naturally chelated by the proteins siderophilin and conalbumin. Biochim. biophys. Acta (Amst.) 1961, 47, 403.

15. Dixon, W. J., and F. J. Massey, Jr. Introduction to Statistical Analysis, 2nd ed. New York, McGrawHill, 1957.

16. Siegel, S. Nonparametric Statistics for the Behavioral Sciences. New York, McGraw-Hill, 1956.
17. Fahey, J. L., and M. E. Lawrence. Yuantitauve uetermination of $6.6 \mathrm{~s} \gamma$-globulins, $\beta_{2} \mathrm{~A}$-globulins and $\gamma_{1}$-macroglobulins in human serum. J. Immunol. 1963, 91, 597.

18. Heide, K., and $\mathrm{H}$. Haupt. Darstellung noch nicht therapeutisch angewandter Plasmaproteine. Behringwerk-Mitteilungen 1964, 43, 161.

19. Vaerman, J. P., H. H. Fudenberg, L. B. Johnson, and W. J. Mandy. Size heterogeneity of normal and pathological $\gamma_{1}$ A globulins. Fed. Proc. 1964, 23, 558.

20. McFarlin, D. E., W. Strober, R. D. Wochner, and T. A. Waldmann. Immunoglobulin A production in ataxia telangiectasia. Science 1965, 150, 1175.

21. Rutstein, D. D., E. F. Ingenito, and W. E. Reynolds. The determination of albumin in human blood plasma and serum. A method based on the interaction of albumin with an anionic dye-2-(4'-hydroxybenzeneazo) benzoic acid. J. clin. Invest. 1954, 33, 211.

22. Schade, A. L. The microbiological activity of siderophilin in Protides of the Biological Fluids, Proceedings of the 8th Colloquium, Bruges, 1960, $\mathrm{H}$. Peeters, Ed. Amsterdam, Elsevier, 1961, p. 261. 